\title{
USPOREDBA REZULTATA NUMERIČKOG PRORAČUNA ZGRADE DOBIVENIH RAZLIČITIM PROGRAMIMA
}

\section{Davorin Pleše}

Sveučilište Josipa Jurja Strossmayera u Osijeku, Građevinski fakultet Osijek, student Ivana Barić

Sveučilište Josipa Jurja Strossmayera u Osijeku, Građevinski fakultet Osijek, mag.ing.aedif. Vladimir Sigmund

Sveučilište Josipa Jurja Strossmayera u Osijeku, Građevinski fakultet Osijek, prof.dr.sc.

Sažetak: Nosiva konstrukcija 3-katne armiranobetonske zgrade je modelirana kao prostorni model s tri različita programa za numerički proračun: SAP2000, Tower 6 i Autodesk Robot 2011, a koji koriste metodu konačnih elemenata (MKE). lako metoda konačnih elemenata može aproksimirati stvarno ponašanje konstrukcije, neminovno se događaju pogreške zbog idealizacije. Ulazni podatci za sva tri programa su isti, a proračunate vrijednosti presječnih sila i deformacija se razlikuju od zanemarivih pa do onih vrijednosti koje treba provjeriti $(>10 \%)$.

Ključne riječi: numerički programi; modeliranje MKE; proračun; usporedba rezultata

\section{NUMERICAL RESULTS OF A BUILDING USING DIFFERENT FEM SOFTWARE}

Abstract: A structural analysis of a common 3-story building has been performed by three different structural analysis software programs, SAP2000,Tower 6 and Autodesk Robot 2011. All three computer programs utilize the Finite Elements Method (FEM) for numerical analysis. Input data of a building structure were the same, as well as the element sizes chosen. Differences in the calculated results, shown in the form of internal forces and deformations, varied from negligible ones to the ones that should be looked upon with suspicion (>10\%).

Key words: numerical software; FEM modeling; analysis; results comparisson 


\section{Općenito}

Metoda konačnih elemenata je numerička metoda koja se koristi za približno rješavanje složenih inženjerskih problema. Osnovni koncept metode je da se realni model kontinuuma s beskonačno mnogo stupnjeva slobode izdijeli na više manjih dijelova. Pritom se svaki dio (konačni element) ponaša kao samostalan, a s ostalima je povezan pomoću čvorova. Tako se kontinuum s beskonačno mnogo stupnjeva slobode svodi na konačan broj elemenata međusobno povezanih u čvorovima. Postupak definiranja konačnih elemenata se naziva diskretizacija, a skup konačnih elemenata mreža. Točna rješenja parcijalnih diferencijalnih jednadžbi zadaća kontinuuma se u metodi konačnih elemenata dobivaju samo u čvorovima, a kvaliteta rješenja unutar elemenata ovisi o primijenjenom konačnom elementu i njegovoj složenosti.

Metoda daje točne rezultate samo u konačnom broju čvorova, zbog čega se kaže da daje približna rješenja inženjerskih i znanstvenih problema. Rezultati (rezne sile, pomaci i dr.) svih drugih točaka konačnog elementa definirani su u odnosu na rezultate u čvorovima. Važno je reći da što je mreža gušća, tj. broj čvorova veći, to su rezultati točniji, jer su poznati u više točaka kontinuuma. Progušćivanjem mreže dobiva se veća konvergencija rezultata, te su oni bliži stvarnima. Međutim, ako se progušćivanjem dobiva divergencija, znači da se javlja pogreška modeliranja (npr. otvori u zidovima i slično).

Pogreške koje mogu nastati primjenom MKE imaju različite uzroke i mogu se podijeliti na grube, sistemske i slučajne. Koeficijent sigurnosti pokriva sistemske i slučajne pogreške, ali grube pogreške ne! Pogreške prouzročene nepažnjom su: proračunske pogreške, krivo zadavanje podataka ili uporabe programa, zanemarivanje određenih proračuna, nedostatak znanja i najčešće, projektant nije svjestan njihova postojanja.

Česte pogreške su i u nedostatnosti proračuna koje su nastale namjerno sa smanjivanjem propisnog korisnog opterećenja; ignoriranjem određenih proračuna (proboj, oslonački pritisci, montažna stanja opterećenja i slično), pogreškama u prijenosu opterećenja, nepoznavanjem propisa, zanemarivanjem nekih utjecaja, itd. Pogreške vezane uz uporabu računala su: pogreške modeliranja (sve do izvedbene dokumentacije), kriva idealizacija nepomičnosti/pomičnosti oslonaca; krivo pretpostavljena krutost; kriva interpretacija rezultata proračuna, naročito za izradu izvedbene dokumentacije.

Radi smanjivanja mogućih pogreški, neophodno je poznavanje teorijskih postavki proračuna, što omogućava inženjersku primjenu programa. Razmišljanje da primjena numeričkih programa uklanja potrebu za znanjima iz statike konstrukcija su pogrešna. Inženjer u modeliranju nekog problema mora znati u kojim granicama su idealizirani pojedini utjecaji, da bi u skladu s time znao procijeniti koliko je očekivano odstupanje njegovog modela, a time i točnost rezultata.

\section{Opis modela}

Radi ilustracije navedenog, izrađen je numerički proračun poslovnog objekta s tri različita programa koji koriste metodu konačnih elemenata i to: SAP2000, ver 14.1, Tower ver. 6.1.4, te AutoDesk-Robot 2011. Korišteni su standardni štapni konačni elementi za stupove, te ljuske za ploče. Pritom se vodilo računa da su dimenzije konačnih elemenata iste, da bi dobiveni modeli imali jednaki broj stupnjeva slobode.

Građevina je armiranobetonska i njezina konstrukcija se sastoji od monolitnih ploča, stupova i zidova. Horizontalna krutost zgrade se osigurava armiranobetonskim zidovima. Građevina je tlocrtne površine $216 \mathrm{~m}^{2}$ $(18 \times 12 \mathrm{~m})$ i sastoji se od podruma, prizemlja, prvog i drugog kata. Podrum je visine 2,60 m, dok su ostale tri etaže visine $3 \mathrm{~m}$, tako da je ukupna visina objekta $11,60 \mathrm{~m}$. Izometrijski prikaz konstrukcija je na slici 1, a njezin karakteristični poprečni presjek i tlocrti na slici 2. Temeljna ploča je $45 \mathrm{~cm}$, krovne ploče $12 \mathrm{~cm}$, a ostale ploče su $18 \mathrm{~cm}$ debele. Zidovi su debljine $20 \mathrm{~cm}$, a stupovi su dimenzija $40 \times 40 \mathrm{~cm}$. Temeljna ploča se oslanja na tlo $\mathrm{s}$ pretpostavljenim modulom stišljivosti $\mathrm{K}_{\mathrm{s}}$ u iznosu od $15 \mathrm{MN} / \mathrm{m}^{3}$.

Konstrukcija se izvodi od armiranog betona klase C $25 / 30$ s modulom elastičnosti $E=30500 \mathrm{~N} / \mathrm{mm}^{2}$. Opterećenja i proračun presječnih sila su provedeni sukladno europskim propisima (HRN EN 0, 1 i 2). 


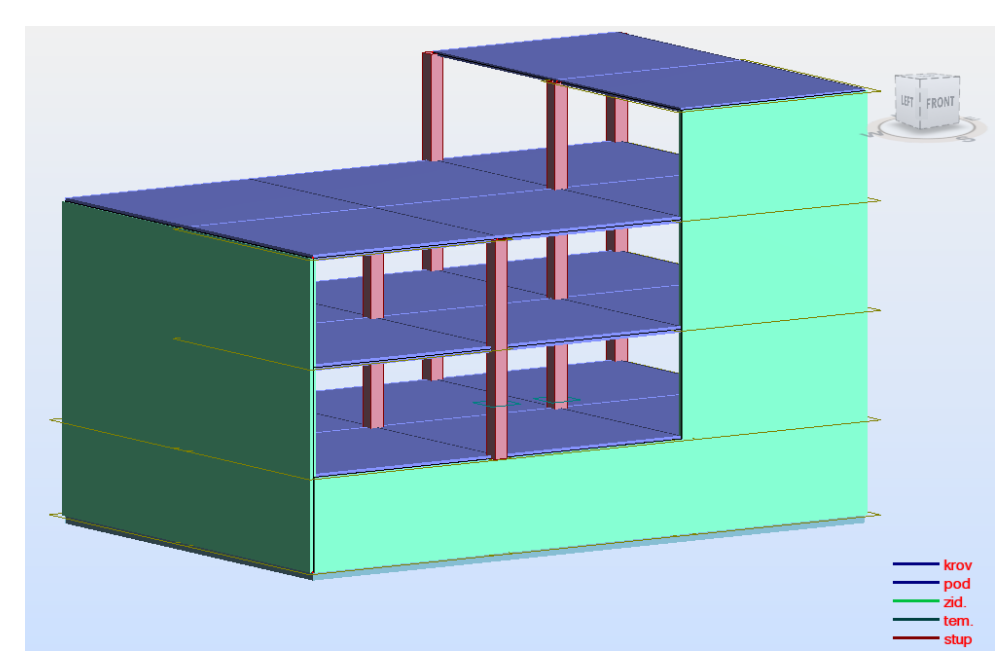

Slika 1 - 3D prikaz modela

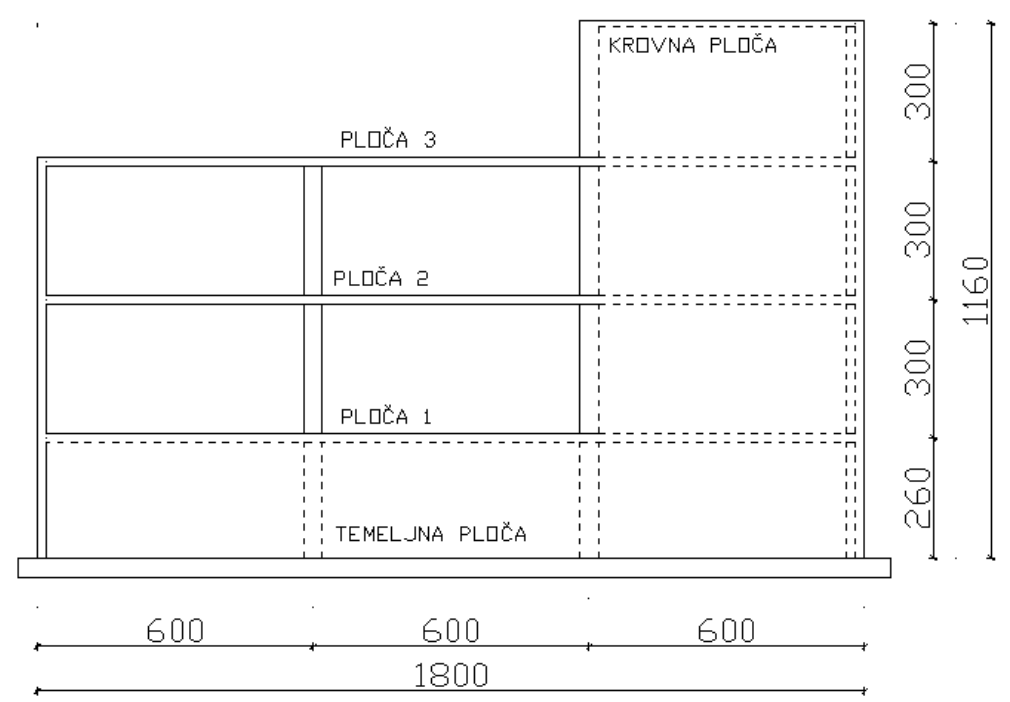

a)

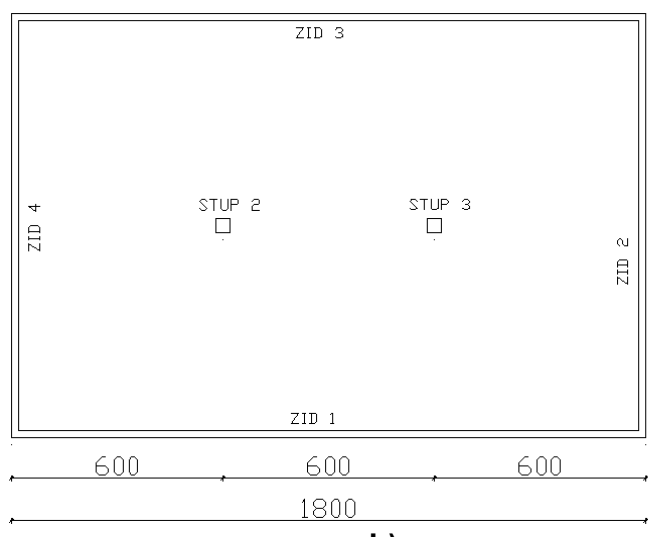

b)

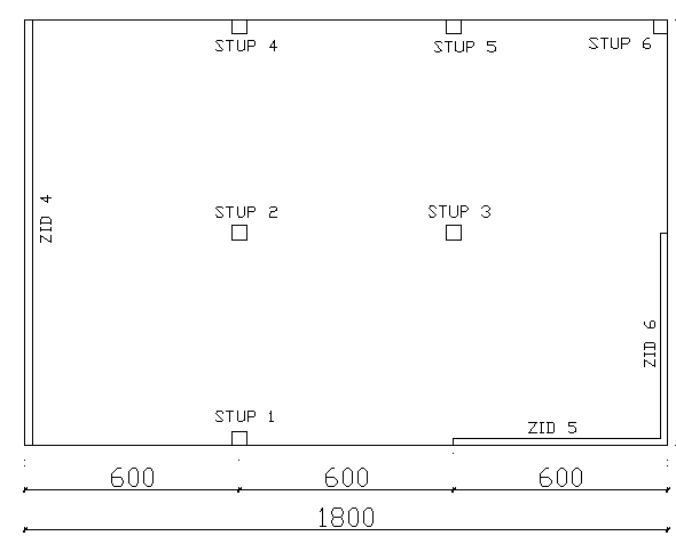

c)

Slika 2 - a) Poprečni presjek građevine, b) Tlocrt podruma, c) Tlocrt prizemlja i prvog kata 


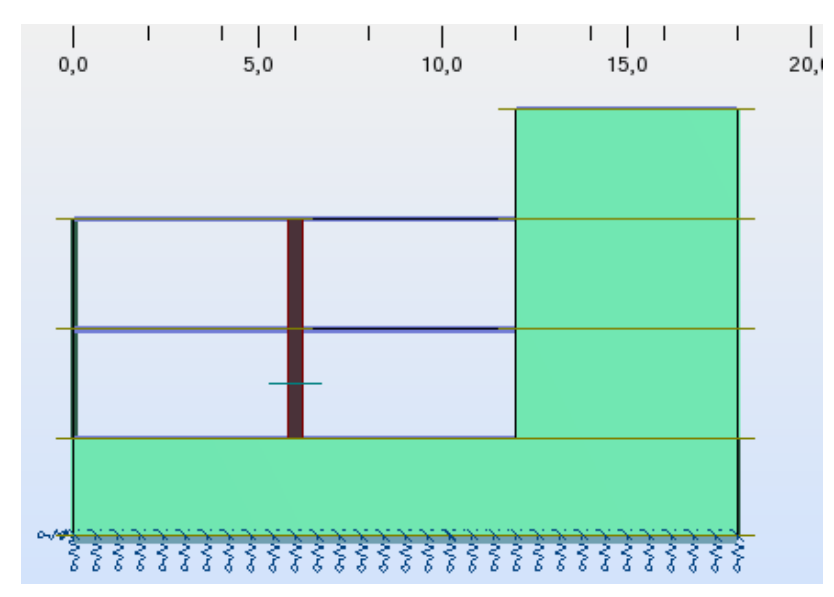

Slika 3 - Modeliranja oslonca temeljne ploče

\subsection{Analiza opterećenja}

Dodatno stalno opterećenje, $\Delta \mathrm{g}$, koje uzima u obzir slojeve poda na ploči, uzeto je u iznosu od $1,5 \mathrm{kN} / \mathrm{m}^{2} \mathrm{i}$ korisno opterećenje, $\mathrm{q}$, iznosi $2 \mathrm{kN} / \mathrm{m}^{2}$. Vlastita težina konstrukcije, $\mathrm{g}$, uzeta je u obzir pomoću programa. Proračun je izrađen za sljedeće kombinacije opterećenja:

- Kombinacija 1: $E_{E D}=1,35 \cdot(g+\Delta g)$

- Kombinacija 2: $E_{E D}=1,35 \cdot(g+\Delta g)+1,50 \cdot q_{1}$

- Kombinacija 3: $E_{E D}=1,35 \cdot(g+\Delta g)+1,50 \cdot q_{2}$

- Kombinacija 4: $E_{E D}=1,35 \cdot(g+\Delta g)+1,50 \cdot\left(q_{1}+q_{2}\right)$.

Rapored korisnog opterećenja q $q_{1}$ q 2 napravljen je po principu „šahovskog polja“ i prikazan je na slici 4.

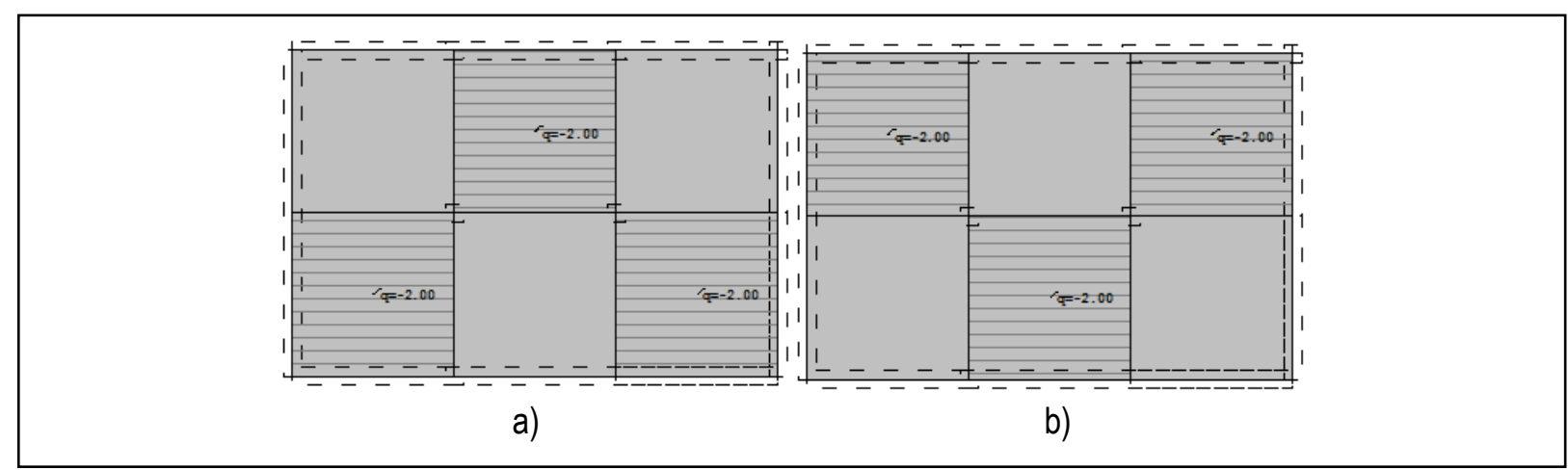

Slika 4 - Način modeliranja korisnog opterećenja na ploči 1

$\begin{array}{lll}\text { a) korisno opterećenje } q_{1}, & \text { b) korisno opterećenje } q_{2}\end{array}$

\section{Usporedba rezultata numeričkih proračuna}

Uz istu geometriju, građevni materijal, propise i opterećenja, napravljeni su numerički proračuni s računalnim programima Autodesk Robot 2011, Tower 6 i SAP2000. Kao mjerodavna kombinacija opterećenja u sva tri programa dobivena je kombinacija 4 i njezini rezultati su uspoređeni tablično. Na slici 5 vidljiva je numeracija stupova i zidova, kao i poprečni presjeci u kojima su očitane presječne sile. Vrijednosti uzdužnih i poprečnih sila su $\mathrm{u} \mathrm{kN}$, a momenata savijanja u kNm. 


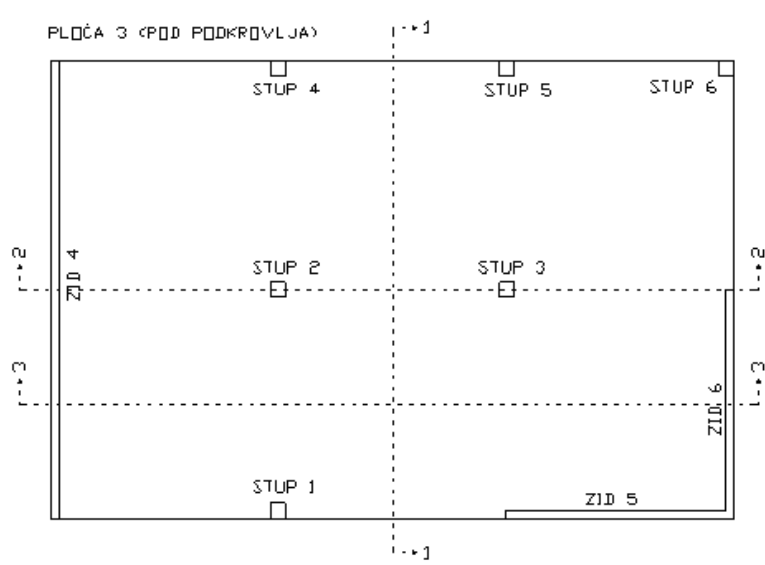

a)

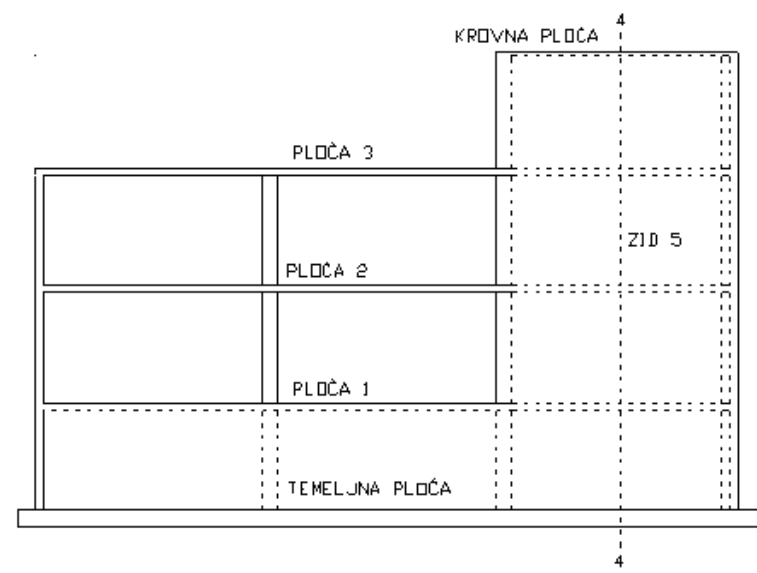

b)

Slika 5 - Mjerodavni presjeci : a) Tlocrt prizemlja i prvog kata, b) Poprečni presjek građevine

Maksimalne vrijednosti presječnih sila u stupovima prikazane su u tablici 1.

Tablica 1 - Vrijednosti presječnih sila u stupovima

\begin{tabular}{|c|c|c|c|c|c|c|c|c|c|}
\hline \multirow{2}{*}{ Element } & SAP & Tower & Robot & SAP & Tower & Robot & SAP & Tower & Robot \\
\cline { 2 - 11 } & \multicolumn{5}{|c|}{$\mathrm{M}_{\max }$} & \multicolumn{3}{|c|}{$\mathrm{T}_{\max }$} & \multicolumn{3}{c|}{$\mathrm{N}_{\max }$} \\
\hline Stup 1 & 77,42 & 76,46 & 65,79 & 37,03 & 42,14 & 41,31 & $-379,31$ & $-382,77$ & $-377,96$ \\
\hline Stup 2 & 9,00 & 9,34 & 9,07 & 2,83 & 3,38 & 2,81 & $-1388,68$ & $-1388,53$ & $-1386,81$ \\
\hline Stup 3 & 12,55 & 13,35 & 12,57 & 8,12 & 8,36 & 8,05 & $-1595,04$ & $-1586,97$ & $-1581,51$ \\
\hline Stup 4 & 66,36 & 74,96 & 64,83 & 4,04 & 5,36 & 3,99 & $-365,90$ & $-369,79$ & $-365,20$ \\
\hline Stup 5 & 46,58 & 52,69 & 45,28 & 18,12 & 19,07 & 18,05 & $-491,46$ & $-493,68$ & $-490,79$ \\
\hline Stup 6 & 33,22 & 36,15 & 32,70 & 16,09 & 18,06 & 15,75 & $-293,12$ & $-294,09$ & $-292,29$ \\
\hline
\end{tabular}

Dijagrami reznih sila za zadane presjeke 1, 2 i 3, dobiveni u računalnom programu Autodesk Robot 2011, dani su na narednim slikama, a u tablicama ispod dijagrama prikazane su pripadne maksimalne vrijednosti izračunate u sva tri računalna programa radi lakše usporedbe. Sve vrijednosti sila dane su u kN/m', a momenata savijanja u kNm/m'.

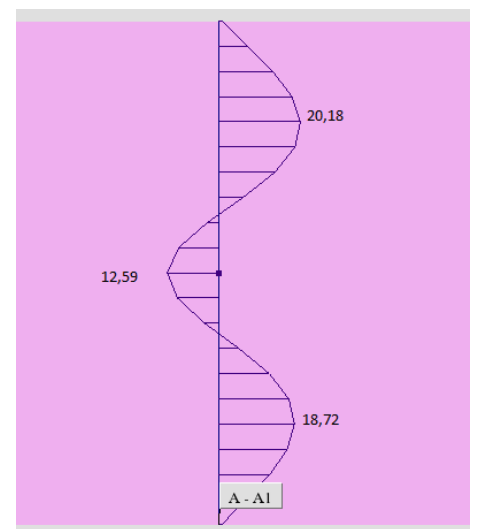

a)

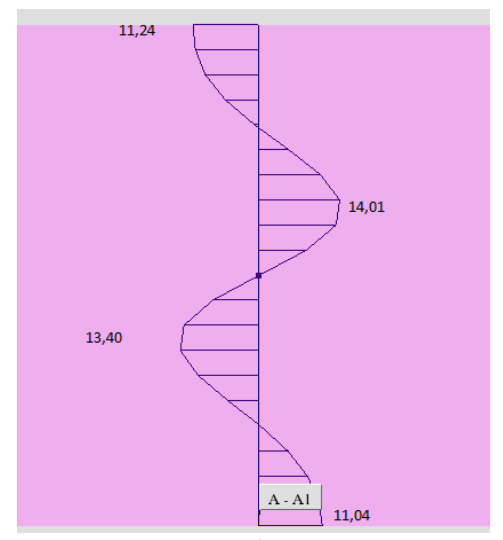

b)

Slika 6 - Moment savijanja $M_{y}$ u presjeku 1-1 (a) i poprečna sila $V_{z, y}(b)$ 
Tablica 2 - Vrijednosti reznih sila u presjeku 1-1

\begin{tabular}{|c|c|c|c|c|c|c|c|}
\hline \multicolumn{5}{|c|}{ My $[\mathrm{kNm} / \mathrm{m}]$} & \multicolumn{4}{c|}{ Vz,y [kN/m] } \\
\hline Robot & 20,18 & $-12,59$ & 18,72 & 11,24 & $-14,01$ & 13,40 & $-11,04$ \\
\hline Tower & 19,32 & $-13,59$ & 18,46 & 10,53 & $-12,19$ & 12,12 & $-10,61$ \\
\hline SAP & 18,33 & $-13,18$ & 20,00 & 9,19 & $-11,61$ & 11,80 & $-9,95$ \\
\hline
\end{tabular}

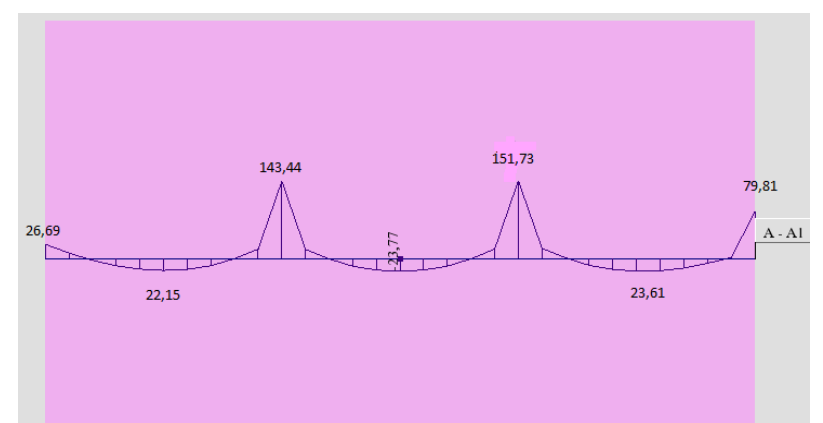

a)

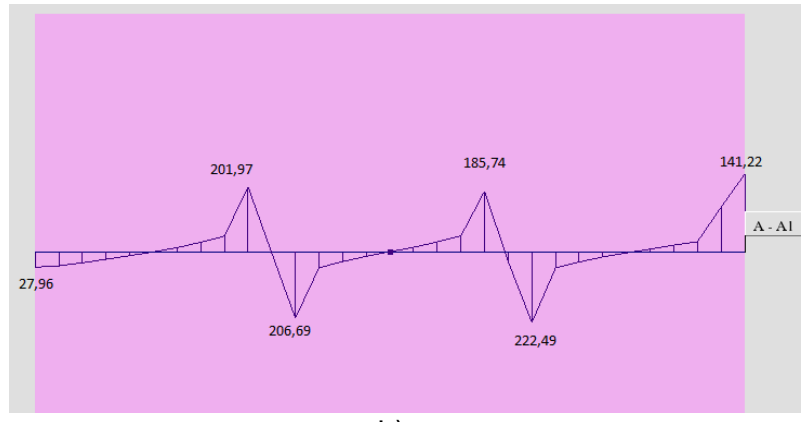

b)

Slika 7 - Presjek 2-2 moment savijanja $M_{x}$ (a) i poprečna sila $V_{z, x}(b)$

Tablica 3 - Vrijednosti reznih sila u presjeku 2-2

\begin{tabular}{|c|c|c|c|c|c|c|c|}
\hline \multicolumn{8}{|c|}{$\mathbf{M} \mathbf{x}[\mathrm{kNm} / \mathrm{m}]$} \\
\hline Robot & $-26,69$ & 22,15 & $-143,44$ & 23,77 & $-151,73$ & 23,61 & $-79,81$ \\
\hline Tower & $-25,99$ & 21,50 & $-123,67$ & 22,73 & $-124,14$ & 23,12 & $-74,47$ \\
\hline SAP & $-26,95$ & 21,50 & $-135,65$ & 22,95 & $-150,92$ & 23,58 & $-75,28$ \\
\hline \multicolumn{7}{|c|}{$\mathbf{V z}, \mathbf{x}[\mathrm{kN} / \mathrm{m}]$} & \\
\hline Robot & $-27,96$ & 201,97 & $-206,69$ & 185,74 & $-222,49$ & 141,22 & \\
\hline Tower & $-31,58$ & 163,47 & $-161,82$ & 147,14 & $-177,37$ & 176,09 & \\
\hline SAP & $-27,66$ & 193,17 & $-195,26$ & 190,86 & $-224,64$ & 104,15 & \\
\hline
\end{tabular}

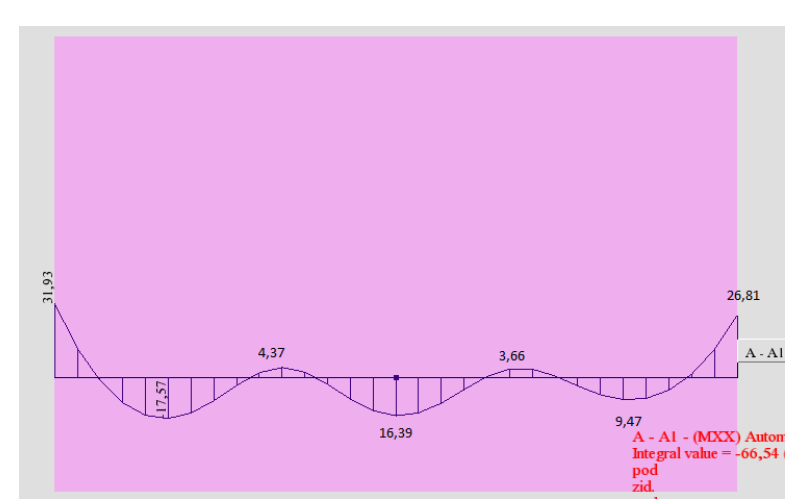

a)

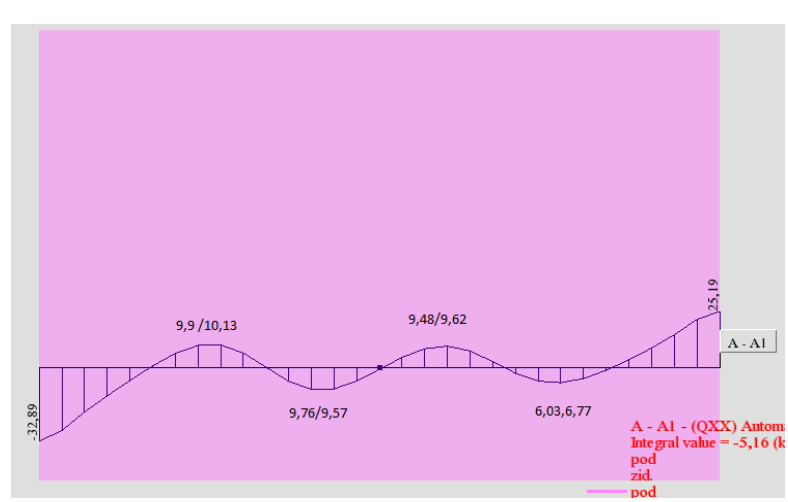

b) 
Slika 8 - Presjek 3-3 moment savijanja $M_{x}(a)$ i poprečna sila $V_{z, x}(b)$ 
Tablica 4 - Vrijednosti reznih sila u presjeku 3-3

\begin{tabular}{|c|c|c|c|c|c|c|c|}
\hline \multicolumn{8}{|c|}{$\mathrm{Mx}[\mathrm{kNm} / \mathrm{m}]$} \\
\hline Robot & $-31,93$ & 17,57 & $-4,37$ & 16,39 & $-3,66$ & 9,47 & $-26,81$ \\
\hline Tower & $-30,25$ & 17,45 & $-5,83$ & 16,16 & $-4,61$ & 9,52 & $-26,35$ \\
\hline SAP & $-30,39$ & 17,16 & $-5,02$ & 16,31 & $-4,08$ & 9,71 & $-25,68$ \\
\hline \multicolumn{7}{|c|}{$\mathbf{V} \mathbf{z}, \mathbf{x}[\mathrm{kN} / \mathrm{m}]$} & \\
\hline Robot & $-32,89$ & 10,13 & $-9,76$ & 9,62 & $-6,77$ & 25,19 & \\
\hline Tower & $-35,44$ & 8,35 & $-8,66$ & 8,66 & $-4,87$ & 29,38 & \\
\hline SAP & $-30,64$ & 7,90 & $-7,62$ & 7,76 & $-4,00$ & 24,38 & \\
\hline
\end{tabular}

Dijagrami presječnih sila za presjek 4-4, dobiveni u računalnom programu Tower 6 , dani su na slikama $9 \mathrm{i}$ 10 , a ispod odgovarajućih slika su tablično prikazane pripadne vrijednosti pojedinih ekstremnih točaka dijagrama, gledajući odozdo prema gore, dobiveni u sva tri računalna programa. Sve vrijednosti sila su dane u kN/m', a momenata savijanja u kNm/m'.

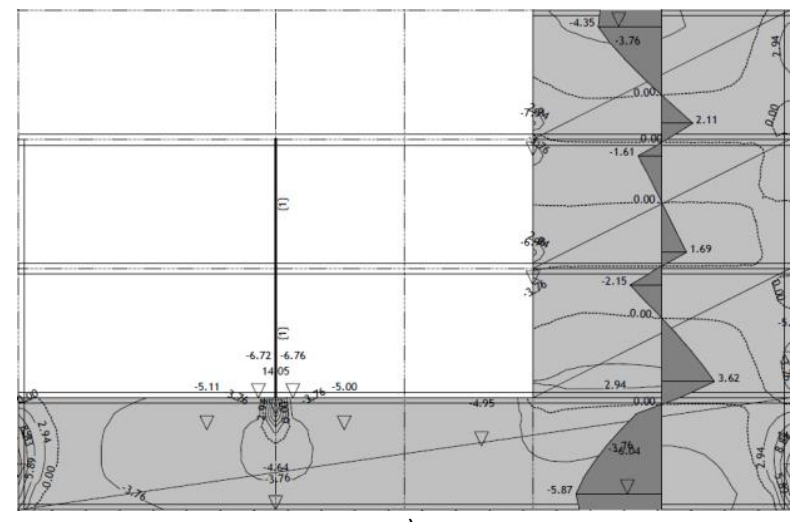

a)

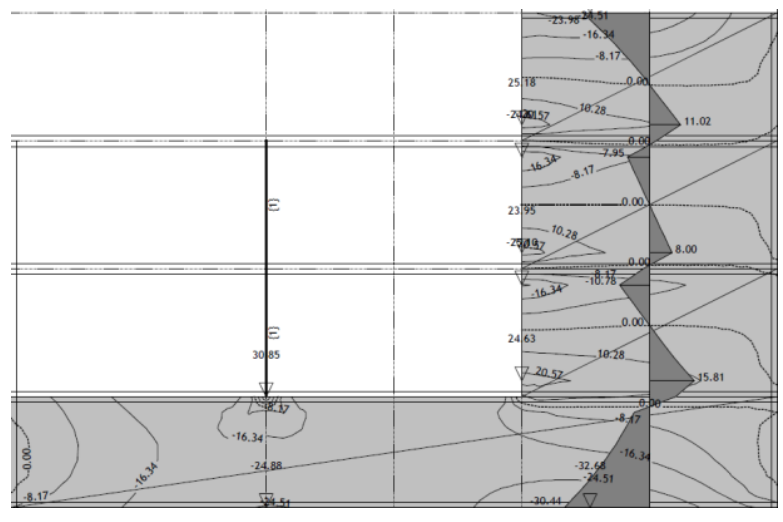

b)

Slika 9 - Presjek 4-4 moment savijanja $M_{x}$ (a) i moment savijanja $M_{y}(b)$

Tablica 5 - Vrijednosti momenata u presjeku 4-4

\begin{tabular}{|c|c|c|c|c|c|c|c|}
\hline \multicolumn{1}{|c|}{ Mx $[\mathrm{kNm} / \mathrm{m}]$} \\
\hline Robot & $-5,95$ & 2,81 & $-1,02$ & 1,07 & $-0,96$ & 0,82 & $-4,87$ \\
\hline Tower & $-5,87$ & 3,63 & $-2,15$ & 1,69 & $-1,61$ & 2,11 & $-4,35$ \\
\hline SAP & $-5,93$ & 3,05 & $-1,46$ & 1,28 & $-1,21$ & 1,35 & $-4,70$ \\
\hline \multicolumn{7}{|c|}{ My $[\mathrm{kNm} / \mathrm{m}]$} \\
\hline Robot & $-30,22$ & 10,65 & $-6,36$ & 5,17 & $-5,14$ & 6,46 & $-24,05$ \\
\hline Tower & $-30,44$ & 15,81 & $-10,78$ & 8,00 & $-7,95$ & 11,02 & $-23,98$ \\
\hline SAP & $-29,90$ & 12,37 & $-8,12$ & 6,10 & $-6,05$ & 8,27 & $-24,27$ \\
\hline
\end{tabular}




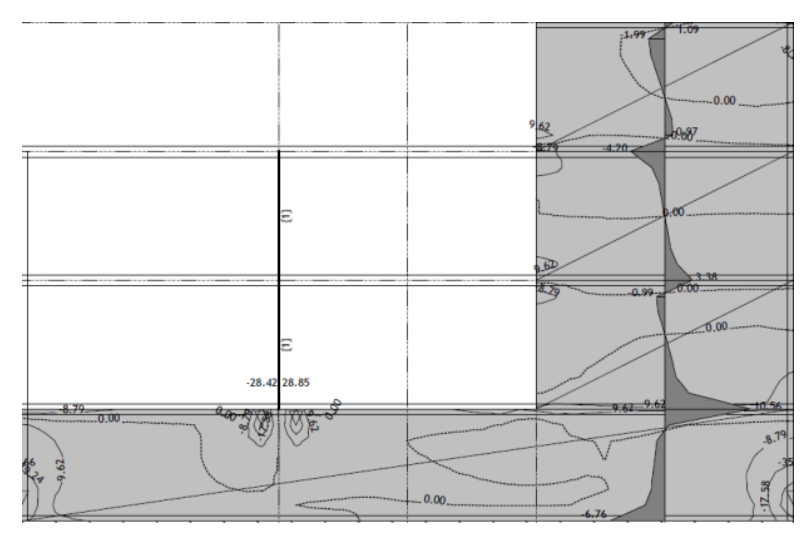

a)

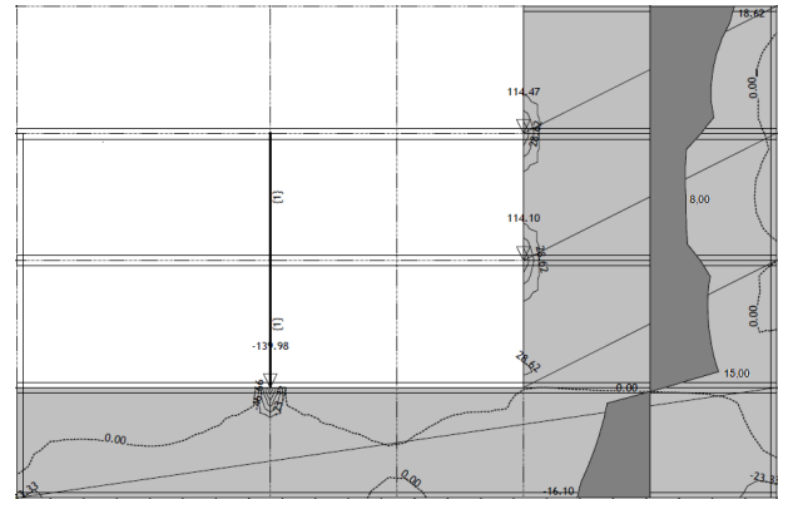

b)

Slika 10 - Presjek 4-4 poprečna sila $V_{z, x}(a)$ i poprečna sila $V_{z, y}(b)$

Tablica 6 - Vrijednosti poprečnih sila u presjeku 4-4

\begin{tabular}{|c|c|c|c|c|c|c|c|}
\hline \multicolumn{8}{|c|}{$\mathbf{V} \mathbf{z}, \mathbf{x}[\mathrm{kNm} / \mathrm{m}]$} \\
\hline Robot & $-2,51$ & 1,45 & $-1,46$ & 0,15 & $-0,33$ & 0,95 & $-0,54$ \\
\hline Tower & $-6,76$ & 10,56 & $-0,99$ & 3,38 & $-4,20$ & 0,97 & $-1,99$ \\
\hline SAP & $-3,85$ & 4,22 & $-1,32$ & 0,62 & $-1,40$ & 1,33 & $-2,28$ \\
\hline \multicolumn{5}{|c|}{ Vz,y $[\mathrm{kN} / \mathrm{m}]$} & & & \\
\hline Robot & $-13,98$ & 12,95 & 7,50 & 16,56 & & & \\
\hline Tower & $-16,10$ & 15,00 & 8,00 & 18,62 & & & \\
\hline SAP & $-13,22$ & 12,85 & 6,97 & 15,90 & & & \\
\hline
\end{tabular}

Proračunati maksimalni elastični progibi ploča, u mm, uspoređeni su u tablici 4.

Tablica 7 - Vrijednosti najvećih elastičnih progiba ploča $(\mathrm{mm})$ na modelima

\begin{tabular}{|c|c|c|c|}
\hline \multirow{2}{*}{ Element } & Sap 2000 & Tower 6 & $\begin{array}{c}\text { Autodesk Robot } \\
\mathbf{2 0 1 1}\end{array}$ \\
\cline { 2 - 4 } & $\mathrm{u}$ & $\mathrm{u}$ & $\mathrm{u}$ \\
\hline Temeljna ploča & 8,3 & 8,2 & 4,0 \\
\hline Ploča 1 & 8,2 & 8,2 & 6,0 \\
\hline Ploča 2 & 8,2 & 8,0 & 6,0 \\
\hline Ploča 3 & 8,2 & 7,9 & 6,0 \\
\hline Krovna ploča & 8,2 & 7,9 & 5,0 \\
\hline
\end{tabular}




\section{Zaključak}

Usporedbom rezultata numeričkih proračuna napravljenih s tri različita programa na istom jednostavnom objektu i uz iste pretpostavke, vidljivo je da se rezultati međusobno razlikuju. Te razlike su različite za različite presječne sile i idu od zanemarivih $(<5 \%)$ pa do onih na koje treba gledati sa sumnjom $(>14 \%)$. Kako inženjer rijetko ima mogućnost usporedbe sa stvarnim rezultatima, pitanje je koji rezultat i koji numerički program daje najmanju pogrešku. U nemogućnosti kalibracije proračuna na eksperimentalnim rezultatima, dobro bi bilo napraviti usporedne proračune na različitim programima da bi se izbjegla pogreška (bug) samog programa. Svaki proizvođač numeričkih programa na svojim početnim stranicama daje izjavu da je korisnik odgovoran za sve dobivene rezultate proračuna. Uzevši u obzir i sve druge moguće izvore pogreški koji su navedeni u uvodnom dijelu rada, vidljivo je da inženjer treba obratiti pozornost na kontrolu kvalitete rezultata te na sustavnu kvalitetu modela.

Stoga, bez obzira koji se računalni program koristi pri modeliranju, nužno je rezultate uzeti sa zadrškom i napraviti kontrolu istih kako bismo znali koliko su pouzdani rezultati dobiveni putem računala. Inženjer statičar nužno mora provjeriti kvalitetu ulaznih podataka i rezultata proračuna, a tu spadaju kontrola ulaznih podataka, kontrola sume vanjskih i unutarnjih sila (djelovanja i reakcija), te kontrola deformacija i sukladnost deformacija s djelovanjima, kontrola s pojednostavljenim nosivim sistemima, proračun s drugačijom mrežom pri proračunu $s$ MKE (ako nije moguće napraviti proračun s drugim programom).

\section{Zahvale}

Posebno zahvaljujemo studentici Kristini Cindrić koja je izradila seminarski rad s proračunom u programu Tower 6. Bez njezinog truda usporedba rezultata s ostala dva programa ne bi bila moguća.

\section{Literatura}

[1] Sigmund, V.: Odabrana poglavlja predavanja iz Metode konačnih elemenata, 2011.

[2] Antonia Jaguljnjak-Lazarević, Josip Dvornik, Lidija Frgić: Utjecaj pogreške zaokruživanja na točnosti proračuna konstrukcije, Građevinar 63 (2011) 11, 911-921

[3] Josip Dvornik, Damir Lazarević: Manjkavosti proračunskih modela inženjerskih konstrukcija, Građevinar 57 (2005) 4, 227-236

[4] Sekulović, M.: Metod konačnih elemenata, Građevinska knjiga, Beograd 1984.

[5] NAFEMS Quality Assurance Procedures for Engineering Analysis, NAFEMS R0064

[6] Vpi (2001), Bundesvereinigung der Prüfingenieure für Bautechnik e. V., Richtlinie für das Aufstellen und Prüfen EDV-unterstützter Standsicherheitsnachweise 